\title{
Green Economy: Issues, Approach and Challenges in Muslim Countries
}

\author{
Negin Vaghefi*, Chamhuri Siwar, Sarah Aziz Abdul Ghani Aziz \\ Institute for Environment and Development (LESTARI), Universiti Kebangsaan Malaysia, Bangi, Malaysia \\ Email: ${ }^{*}$ negin.vaghefi@gmail.com, csiwar@ukm.edu.my, saziz@ukm.edu.my
}

Received 9 January 2015; accepted 28 January 2015; published 30 January 2015

Copyright (C) 2015 by authors and Scientific Research Publishing Inc.

This work is licensed under the Creative Commons Attribution International License (CC BY). http://creativecommons.org/licenses/by/4.0/

(c) (;) Open Access

\begin{abstract}
Developing countries like most of Islamic countries need an economy that promotes growth and development, conserves natural capital, creates jobs, improves human well-being, and alleviates poverty and inequality. Such an economy is called green economy. Main problems that create a hard situation to implement green economy in most of Islamic countries are weak management, increasing poverty, many local and border conflicts, high economic dependency on natural resources, and increasing food insecurity. Governments as policy makers could introduce policies, regulations and incentives to promote green economy. This paper therefore attempts to discuss on how green economy can improve the livelihood security and poverty eradication in Islamic countries. It also seeks to understand which key intervention is needed to achieve a green economy in Muslim countries.
\end{abstract}

\section{Keywords}

Green Economy, Sustainable Development, Islamic Countries

\section{Introduction}

Based on sustainable development concept, the economy is not separate from the environment in which we live. The way we manage the economy impacts the environment, while the environmental quality impacts the performance of the economy. The economic growth is usually accompanied by environmental degradation. Degradation of environment generates a poverty trap, which causes a reinforcing loop of further degradation and worsening poverty. Thus, environmental challenges increase critical concerns for the welfare of current and future generations [1]. There is a growing concern about global economy, environmental development and social equity in many countries. It has also been increased by recent global financial, energy and food crises. Hence, to

"Corresponding author. 
overcome these concerns, green economy has been proposed as an important tool to achieve sustainable development. Many countries are promoting a green economy which is a clean and energy efficient economy. United Nations Environment Programme (UNEP) defined green economy as "one that results in improved human wellbeing and social equity, while significantly reducing environmental risks and ecological scarcities". It could also be thought as one which was low carbon, resource efficient and socially inclusive [2].

The Islamic perception of the natural resources has its roots in the Holy Quran. The Quran contains some important principles for environmental conservation and shows that environmental damage and mismanagement of natural resources are disliked. According to Holy Quran, "Eat and drink: But be not excessive. Indeed, God does not like those who commit excess" (Surah Al-A'raf 7:31; Al-An'am 6:141). In the Quran, it is also stressed that "the wasteful are brothers of the devils, and ever has Satan been to his Lord ungrateful" (Surah Al-Isra' 17:27). Based on these statements, conservation of all natural resources from misuse is mandatory duty. In fact, the Holy Quran and Islamic law can play an important role in promoting sustainable development in Islamic countries.

There is an urgent need for Islamic countries to be greener in management and business due to the equitable law in Islam, whereby the correlation between greenness and the equitable law is very close. Khaliq [3] and Mohd Yusof et al. [4] emphasized the need for leadership in Islamic countries to successfully implement green management. Without appropriate management, great ideas could not be implemented for the purpose of achieving green economy. They believe that Muslim countries will be more developed if their people lead their life based on the principles of Islam. Islam and Islam [5] conducted research about Muslim institutions and its contribution to developing a healthy society. They found that a strong family institutions and practicing Islam properly could lead to practice cleaner and greener management.

The Organisation of Islamic Cooperation (OIC) is the second largest inter-governmental organization after the United Nations. It has membership of 57 Islamic countries spread over four continents. One of the aims of this organisation is to achieve sustainable and comprehensive human development and economic well-being in member countries. Many characteristics of the OIC member countries make them extremely vulnerable to natural and human made hazards. For example, some of them are among the most disaster prone areas of the world, like African countries, and some of them are suffering from significant human causalities and economic losses, like Pakistan and Iraq. So far, a few OIC member countries have adopted their national sustainable development strategies. For instance, Malaysia successfully adopted sustainable development strategies to become a fully developed country by year 2020 through the effective strategic planning [6]. United Arab Emirates is maintaining sustainable development and providing a safe environment. Among Persian Gulf countries, United Arab Emirates has been a leader in applying clean technology and alternative sources of energy in the past few years. Development of a sustainable international tourism industry in Turkey, Malaysia, Indonesia, Egypt, Tunisia and Morocco is another example in this regard [7].

Different Muslim countries may adopt sustainable development policies and strategies differently. It depends on their social, economic and environmental situation. Geographic location of undeveloped countries could also be a critical factor in delaying their development. Muslim countries are at different levels of economic development. Out of the world's remaining 48 Least Developed Countries (LDCs), 21 are Islamic countries whose development depends on the export of non-oil products such as agricultural products. However, growth and development of around 17 Islamic countries, which are categorized as high or upper middle income nations, mostly depends on the export of oil and gas [8]. The development gap between low-income and high-income countries has continued to widen, and it causes a challenge for sustainable development.

\section{Environmental Issues in Muslim Countries}

Islamic countries have great variety of natural resources, environment, and geography. Most of them have arid and semiarid climate which caused to have a desert environment, especially in the Middle East and North Africa. Thus, they are extremely vulnerable to climate change in terms of water availability which mostly threatens their agriculture. This climate also caused to have small proportion of forest area. Deforestation is one of the important environmental issues in Islamic countries. Average annual deforestation in OIC countries is presented in Figure 1. Among these countries, African countries like Comoros, Togo, and Nigeria have highest rate of deforestation. Since the urbanization in most Islamic countries is expanding, particularly in Malaysia and Turkey, the forest area is experiencing intensified pressure from deforestation. Forests provide habitat for various species 
Average Annual Deforestation (\%)- (2000-2011)

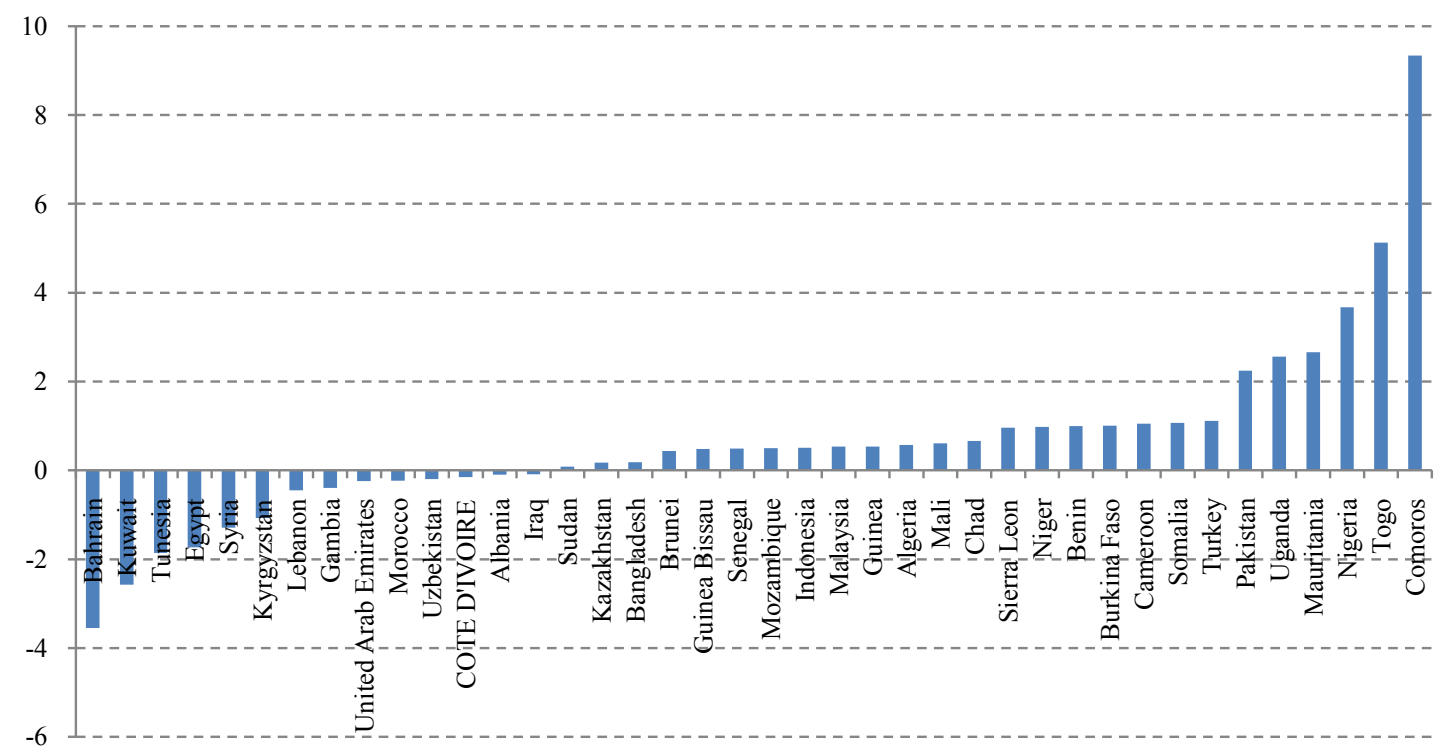

Figure 1. Average annual deforestation in selected Islamic countries from 2000-2011 (source of data: World Bank, 2013) [18].

and acts as sink of carbon, therefore, deforestation generates stresses on environment. It also threatens the welfare of people who their livelihood depends mostly on forest resources.

Some of the Muslim countries which are located in South Asia, South East Asia, North Africa and Middle East are affected by extreme weather such as drought and flood. Most of them are suffering from the weak capacity to mitigate the adverse impact of extreme conditions. These regions are highly subject to natural hazards, for instance, the 2004 Indian Ocean Tsunami in Indonesia and the 2005 Pakistan Earthquake. Such impacts pose additional risks for communities that are trying to reduce poverty and achieve sustainable development. Furthermore, unsustainable exploitation of natural resources such as coral reefs and mangrove forests is the cause of floods in Pakistan. In south-eastern Bangladesh, destruction of mangrove forests resulted in degradation of the habitat and species lost as well [9]. Rapid urbanization in countries like United Arab Emirates, Bahrain, Malaysia, and Turkey increased energy used, solid waste, and therefore GHG emission which could be contributed to the climate change. Overexploitation, urbanization, climate change, and other environmental factors are resulting in ecosystem and biodiversity loss and destroying the benefits associated with natural resources. Thus, it is necessary for the Islamic countries to protect their natural capital and put their policies on the sustainable development pathway.

\section{Socio-Economic Issues in Muslim Countries}

The social dimension in the Islamic countries needs immediate attention. Some of the OIC member countries such as Indonesia, Bangladesh and Pakistan are the most populous countries. High population growth imposes pressure on all dimensions of sustainable development. The economy of Muslim countries differs from low to medium and high income. Based on World Bank classification, 18 OIC countries are classified as low income countries, 34 are middle income (18 lower middle and 16 upper middle), and 7 countries are categorized as high income countries. Figure 2 shows the per capita GDP in the OIC countries. It indicates that there is a significant gap between the rich and the poor countries in 2011.

The economic crisis and global financial of 2008-2009 has also affected the socio-economic development in Muslim countries. In some of them the GDP growth decreased, and others had been affected by high fuel and food prices. Indeed, these countries influenced by the decline in economy growth and development as well as increase in unemployment and poverty. However, green economy mostly focuses on efficient use and conservation of natural capital to expand the economy which provides indemnity against the possible pressures of world economy. 


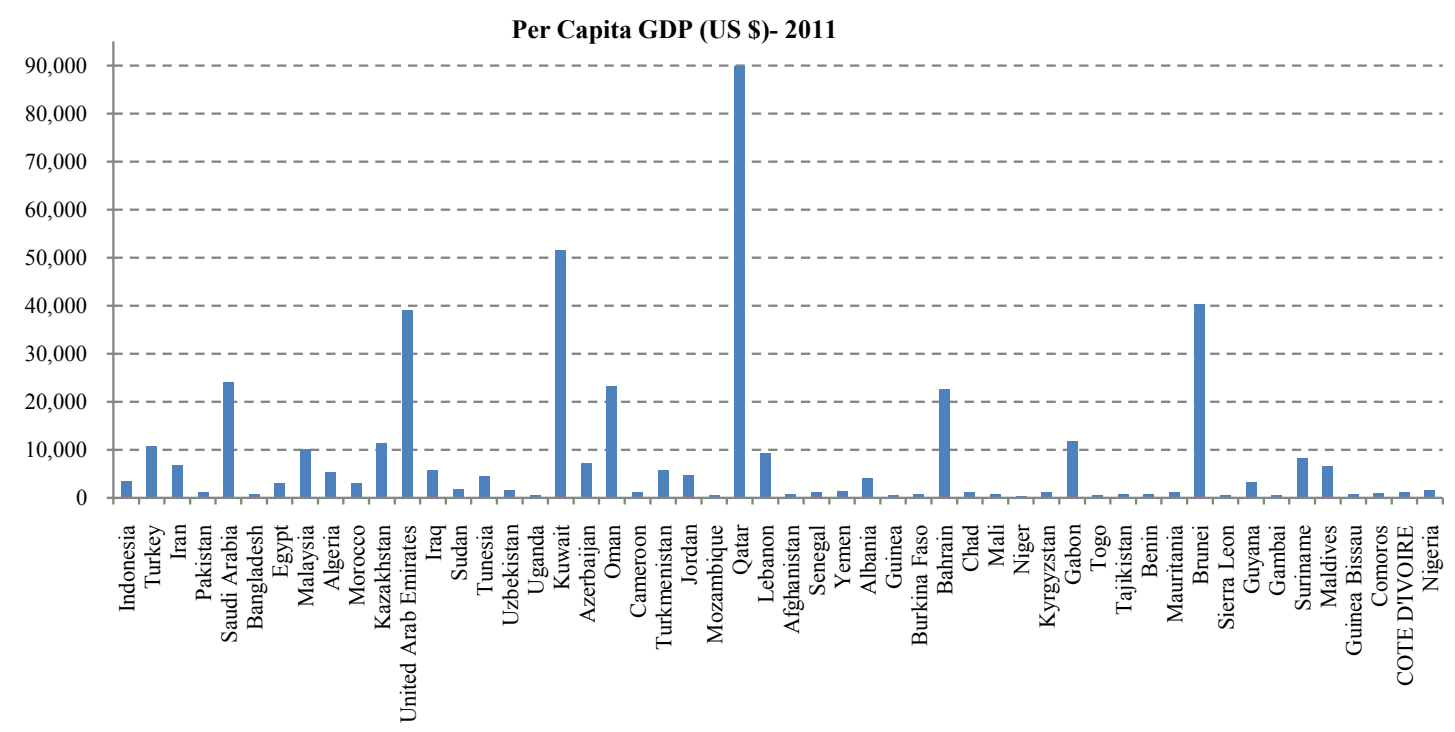

Figure 2. Comparison of Per capita GDP of OIC member countries (except Syria, Libya, Somalia, Djibouti and State of Palestine) (source of data: World Bank, 2011).

\section{Poverty in Muslim Countries}

There is a relationship between average income of the country and poverty. As countries become richer the incidence of poverty falls. The poverty ratio in Muslim countries is almost high. Table 1 shows the percentage of the poor whose their income is below the poverty line as a percentage of total population. This table presents information for some lower middle income and low income OIC countries that data could be obtained. Among these countries, percentage of population living on less than $\$ 1.25$ a day in Nigeria, Mali, Burkina Faso and Bangladesh is relatively high. Poverty gap at national poverty line is the mean shortfall from the poverty line. This measure indicates the depth and incidence of poverty in these countries. Just seven countries out of 57 OIC members classified as high income countries which is mostly due to their high oil revenues. Although about 17 oil producing and exporting countries (OPEC) have crude oil and refinery industries, most of them do not have main industrial base. Around 22 out of 50 least developed countries of the world are the OIC member states ("General Framework" [10]). Among OIC countries, most of low income (e.g. Bangladesh) and lower middle income (e.g. Indonesia and Pakistan) countries has high population growth and unequal income distribution. Most of them do not access to the resources required for a suitable standard living and their life expectancy at birth is almost low (e.g. 50 years for Chad). In some low income countries like Afghanistan, rural poverty is very high which is due to inadequate access to land, lack of irrigation infrastructure, high illiteracy rate, and living in remote areas. Besides, the poverty in some Islamic countries corresponds with increasing conflicts and tensions in these countries which needs attention from international communities. Poverty alleviation and income equality are the most important economic goals of Islam. To achieve these goals, the socio-economic processes and environmental priorities should be interacted to support the sustainable development concept.

Transition to green economy could generate great opportunities of green jobs in the different economic sectors. Most Muslim countries' economy depends on agriculture (Sub Saharan African countries and Surya), natural resources (countries around the Persian Gulf), and mineral resources (Morocco and Mauritania). Greener economy would support rural communities who their livelihoods depend on natural resources, through conservation and proper investment in natural capital, and make a good economy sense. It may bring solutions to unemployment issue which is an important socioeconomic issue in Muslim countries, especially in Arabian countries with high youth population. Since the population of Muslim countries is constituted one fifth of the world's population, they could be invested through job creation by government to promote economic growth, increase income, reduce poverty, and finally to achieve the sustainable development.

\section{Green Economy in Muslim Countries}

Developing countries like most of Islamic countries need an economy that promote growth and development, 
Table 1. Per capita GDP and Poverty in selected OIC countries.

\begin{tabular}{|c|c|c|c|c|}
\hline Countries & $\begin{array}{l}\text { Per capita GDP } \\
\text { (US dollars) }\end{array}$ & $\begin{array}{c}\text { Poverty gap at } \\
\text { national poverty line (\%) }\end{array}$ & $\begin{array}{l}\text { Poverty headcount ratio at } \$ 1.25 \\
\text { a day (PPP) ( } \% \text { of population) }\end{array}$ & $\begin{array}{l}\text { Poverty headcount ratio at } \$ 2 \text { a day } \\
\text { (PPP) (\% of population) }\end{array}$ \\
\hline Tunesia & 4207 & 4 & 1.1 & 4.3 \\
\hline Indonesia & 2947 & 2 & 18 & 46 \\
\hline Nigeria & 1437 & 17 & 68 & 84.5 \\
\hline Sudan & 1422 & 16 & 19.8 & 44 \\
\hline Kyrgyzstan & 1124 & - & 6.7 & 22.9 \\
\hline Tajikistan & 880 & - & 6.6 & 27.7 \\
\hline Benin & 690 & 10 & - & - \\
\hline Mali & 676 & 13 & 50 & 79 \\
\hline Bangladesh & 664 & 7 & 43 & 77 \\
\hline Burkina Faso & 593 & - & 44.6 & 72.6 \\
\hline Gambia & 566 & 28 & - & - \\
\hline Afghanistan & 561 & - & - & - \\
\hline Guinea Bissau & 527 & - & - & - \\
\hline Uganda & 506 & 7 & 38 & 65 \\
\hline Togo & 503 & 24 & 28.2 & 53 \\
\hline Sierra Leon & 448 & 16 & - & - \\
\hline Guinea & 435 & - & - & - \\
\hline Mozambique & 387 & 21 & - & - \\
\hline Niger & 360 & - & - & - \\
\hline
\end{tabular}

(Source of data: World Bank, 2010).

conserve natural capital, create jobs, improve human well-being, and alleviate poverty and inequality. Such an economy is termed green economy. Main problems that create a hard situation to implement green economy in most of Islamic countries are weak management, increasing poverty, many local and border conflicts, high economic dependency on non-renewable and renewable natural resources, and increasing food insecurity. In addition, there are other social and environmental challenges that hinder green entrepreneurs and grassroots initiatives to provide innovation solutions for transition to green economy in some Islamic countries. These conditions are included the limited access to investment, lack of public support for entrepreneurs, weak environmental legislation, lack of market incentives, poor entrepreneurial culture, low interest from consumers, and governmental bureaucracy [10].

Governments as policy makers could introduce policies, regulations, and incentives to promote green economy. They could also invest in green technology, renewable energy, green building, green agriculture, green tourism, green transport, etc. They need to develop public and private sectors to handle such assessments. Government investment program could create new employment opportunities. In other words, transition to green economy creates green jobs, such as renewable energy generation, ecosystem protection, ecotourism, etc, which in turn would reduce the unemployment rate in Muslim countries. Here are some examples of Muslim countries that have been successfully implemented green economy and shows that there is a growing interest among Islamic countries to take the opportunity to move towards a green economy.

\subsection{Uganda}

In Uganda, around 85 percent of the people's livelihood was depended on agricultural production which contributed to 42 percent of the national GDP and 80 percent of the export earnings in 2005-2006. In 1994, Uganda 
had a general movement in the agricultural sector towards developing sustainable agriculture to improve people's livelihood. In 2003, they had 13th largest land area under organic agriculture production in the world. They benefits from an important source of export earnings and revenue for farmers. Their strategy for policy implementation is based on interventions in nine policy areas included the promotion of organic agriculture as a complementary agricultural production system; the development of a system of standards, certification and accreditation; the promotion of research to enable technology development; support to the development of local, regional and international markets for organic products; the generation of information, knowledge and skills through education and training; the improvement of post-harvest handling practices, preservation, storage and value addition; the sustainable use of natural resources; and participation of the special interest groups such as women, youth, and poor people. By organic farming, Uganda not only obtains socially and economically benefits, it also helps to mitigate the adverse impact of climate change such as GHG emission [11].

\subsection{Indonesia}

In Indonesia, green economy strategies need to be integrated with international and national development goals. The Indonesian government is considering green economy options in their regional development and economic corridor approaches. Green economy policies are being delivered through a number of action plans for low carbon development and less hazardous waste, sustainable use of biodiversity, and natural carrying capacity. Phasing out of undesired subsidies for fossil fuels shifted incentives away from resource use and pollution. For instance, the government has started to phase out the use of kerosene for household cooking, which is highly subsidized, to liquefied petroleum gas.

Since Indonesia is one of the most populous countries, access to safe water and sanitary condition is very important issue. A private water utility, Palyja, is responsible for water supply in Western Jakarta and is expected to supply water to all people who live in this area. Palyja is evaluating the giving access to groups of informal houses by establishing community-based organizations. Each organization is given access to a single master water meter and is responsible for the management of the community's water supply infrastructure and paying for the volume of water taken. Under this condition, the community gets reliable access to an inexpensive water supply, while Palyja supplies a large number of houses with water at much lower overhead and administrative costs $[10]$.

\subsection{Malaysia}

The process of greening Malaysia's economy had started around the 1970s with introducing the regulations to manage pollution from the palm oil industry. Malaysia's policy framework in energy development gradually developed by focusing on fossil fuel supply in the 1970s to a diversification of supply sources (renewable energy) by the year 2000. In 2009, Malaysia introduced a new development policy framework called the New Economic Model which outlined the goals of inclusiveness, high income and sustainability to lead Malaysia to a high income country by 2020 . Malaysia has also introduced the systematic architecture to respond to the green economy agenda [12]. The Malaysian national green technology policy (NGTP) which was introduced in July 2009 shall be a driver to accelerate the national economy and promote sustainable development. The energy efficiency and renewable energy will be also promoted and supported under this policy [13]. NGTP tries to develop and improve the major sectors such as energy, buildings, water and waste management, and transportation. Moreover, it tries to progress and improve R \& D, innovation and commercialization through collaboration with local and multi-national companies [14].

The Malaysian government has started some basic and feasible fiscal and financial green technology development incentives. Many Malaysian companies are financing their green technology initiatives through Islamic banks. However, financing of green technology through Islamic banks in the Middle East is still at developing stage. Green technology financing scheme (GTFS) is a government initiative to encourage investments in green technology which may also lead to economic growth and achieving a sustainable development. There is a positive relationship between financial sector development and the economic growth. Financial development could have impact on the degree of inclusiveness of economic development.

\subsection{Turkey}

Turkey is an energy importing nation which more than $70 \%$ of its energy requirements met by imported fuels. 
Air pollution is an important environmental concern in this country. Hence, hydropower and other renewable energy sources became good solution for clean and sustainable energy of Turkey. Turkey has adopted energy efficiency to reduce the country's Carbon Dioxide emission. Turkey decreased its Energy intensity by $8 \%$ between 1990 and 2005. Its improvement through improved sectoral energy efficiencies is an important goal of Turkey. It has multiple benefits such as economic benefits, environmental benefits and health benefits. Turkey has large energy conservation potential around 25\% - 30\%. Energy efficiency policies have been implemented in the industrial, residential and services sectors. Its National Energy Conservation Centre has provided training to consumers on energy conservation measures, conducted energy audits in industry, maintained energy consumption statistics for the industrial sector and public buildings, and co-ordinated dialogue and co-operation with the relevant institutions. There is a great potential for geothermal, solar thermal, wind power and solar energy applications in Turkey [15].

\subsection{Arab Countries}

Many of Arabian countries are implementing the green economy to achieve the sustainable development. For example, United Arab Emirate created sustainable public transportation in Dubai by establishing the subway network to bring about 30 percent reductions in private car use. As a result of that, greenhouse gas emissions would reduce because of using the renewable energy. In addition, the natural gas has been increasingly used for taxi vehicles in countries like Egypt, Syrian Arab Republic, and United Arab Emirate.

Saudi Arabia has constructed many environment-friendly buildings inspired by traditional architectural concepts to prepare the easy way for future architectural achievements. For example, King Abdullah University of Science and Technology (KAUST) with innovative designs, such as natural solar lighting, solar cooling, and solar power, aims at reducing the need for electrical lighting and cooling, and saving annual energy costs. In June 2014, Qatar launched its green economy roadmap which represents a comprehensive effect to assist in the development and implementation of policies towards a green economy. Moreover, Qatar is significantly implementing sustainable building practices and it is sixth in the world in green buildings. Bahrain and Kuwait are also implementing sustainable buildings. Some of these buildings are integrated with wind turbines like Bahrain World Trade Centre, and some with Photovoltaic like the Euro-University in Bahrain, and the English School in Kuwait [16]. In Morocco, a solar power plant was established in 2010 which is expected to cover about 13 percent of the country's power needs. Among Arab countries, Egypt has developed a leading experience in applying wind energy. The government of Egypt allocated around $7647 \mathrm{~km}^{2}$ of land for wind farms with almost free land access for investors. They have planned to increase the renewable energy share of total electrical production to 20 percent by 2020 (12 percent from wind energy) (“Green Economy in the Arab Region" [17]).

Tunisia has promoted the development and use of renewable energy to decrease the country's dependency on oil and gas. In 2009, the first national Solar Energy Plan was presented with the objective of increasing the share of renewable energy sources from just under 1 percent to 4.3 per cent in 2014 . The plan includes the use of solar photovoltaic systems, solar water heating systems and solar concentrated power unit for electricity generation. The expected energy savings from the Solar Energy Plan may reach 22 percent for 2016, with a reduction of 1.3 million tonnes per year of $\mathrm{CO}_{2}$. The experience in Tunisia indicates the potential returns on investing in renewable energy as one of the pillars of green economy, creating new jobs, and reducing dependency on fuel imports [11].

\section{Concluding Remarks}

Some Muslim countries are blessed with the wealth of crude oil and gas. It has contributed to the development of their countries, and most of them have become high income countries, like Qatar, Kuwait, Brunei, United Arab Emirate, Saudi Arabia, Bahrain and Oman. These countries are successfully implementing their national green economy strategies. However, lower income countries such as Togo, Afghanistan and Mozambique are still far from green economy practices. The critical issue among OIC countries is the insufficient capacity for effective risk management and the vulnerability to various classes of risk. For example, Pakistan, Indonesia and Bangladesh are regions with high potential of natural hazards and weak capacity to mitigate the adverse impact of extreme conditions. In this regard, there is an urgent need to increase research and development capacity for adopting green economy strategies in these countries.

Transition to green economy could reduce environmental degradation and protect society from the adverse 
impact of economic growth. Attentive movement towards green economy may find new ways to enhance resource efficiency and open new opportunities for socio-economic development. Strategies to obtain green growth may lead to better living conditions in Muslim countries. Without technological changes and innovation, complete implementation of green economy is not possible. In fact, no government has all the technologies, financials and resources required for transition to green economy. Hence, Islamic countries need international help from developed countries, as well as more cooperation between OIC member countries. Moving towards green economy should aim at increasing regional partnership and encouraging joint projects among Islamic countries. It may give power to OIC member countries in order to deal with the existing constraint of the lack of inclusive framework for a green economy in Muslim countries.

\section{Acknowledgements}

This work was prepared under research projects ERGS/1/2013/SS07/UKM/01/1 and

FRGS/1/2012/SS07/UKM/01/3 led by Professor Chamhuri Siwar and DPP/2013/073 led by Associate Professor Dr. Sarah Aziz Abdul Ghani Aziz at Universiti Kebangsaan Malaysia (UKM).

\section{References}

[1] Szovics, P., Tessaring, M., Walmsley, C. and McGrath, J. (2009) Future Skill Needs in the Green Economy. Cedefop Research Paper, Thessaloniki.

[2] UNEP (2011) Towards a Green Economy: Pathways to Sustainable Development and Poverty Eradication-A Synthesis for Policy Makers. www.unep.org/greeneconomy

[3] Khaliq, A. (2008) Challenges and Practices in Human Resources Management of the Muslim World. The Journal of Human Resource and Adult Learning, 4, 34-42.

[4] Mohd Yusofa, F., Rosmana, A.S., Mahmoodb, S., Saripc, S.H.M. and Noh, T.U. (2013) Green Technology Management in the Muslim World. Journal Teknologi, 65, 107-115.

[5] Islam, M.K. and Islam, R. (2011) Strengthening Muslim Family Institution: A Management Perspective. Pertanika J. Soc. Sci. \& Hum., 19, 81-97.

[6] Ponrahono, Z., Che Omar, C.M., Makmom Abdullah, A. and Muda, A. (2011) Matrix Sustainable Strategies Compatibility Analysis of Malaysia's Sustainable Development Strategies in Three-Tier Development Plan System. World Applied Sciences Journal, 14, 22-30.

[7] SESRTCIC (2006) International Tourism in the OIC Countries: Prospects and Challenges. Journal of Economic Cooperation, 27, 101-138.

[8] International Monetary Fund (IMF) (2013) World Economic Outlook 2013: Hopes, Realities, Risks, April.

[9] Islam, S.N. and Gnauck, A. (2008) Mangrove Wetland Ecosystems in Ganges-Brahmaputra Delta in Bangladesh. Frontiers of Earth Science in China, 2, 439-448. http://dx.doi.org/10.1007/s11707-008-0049-2

[10] (2012) Draft Updated Version of the General Framework of the Islamic Agenda for Sustainable Development. Fifth Islamic Conference of Environment Ministers. http://www.sesric.org/imgs/news/image/702-framework-of-islamic-agenda.pdf

[11] UNEP (2010) Green Economy: Developing Countries Success Stories. United Nations Environment Programme. http://www.unep.org/pdf/greeneconomy_successstories.pdf

[12] Hezri, A.A. and Ghazali, R. (2011) A Fair Green Economy? Studies of Agriculture, Energy and Waste Initiatives in Malaysia. Occasional Paper Two, Social Dimensions of Green Economy and Sustainable Development. http://www.fes-globalization.org/geneva

[13] NGTP (2009) National Green Technology Launched Today. Press, NST Online, 24 July.

[14] Chua, S.C. and Oh, T.H. (2011) Green Progress and Prospect in Malaysia. Renewable and Sustainable Energy Reviews, 15, 2850-2861. http://dx.doi.org/10.1016/j.rser.2011.03.008

[15] Yuksel, I. and Kaygusuz, K. (2011) Renewable Energy Sources for Clean and Sustainable Energy Policies in Turkey. Renewable and Sustainable Energy Reviews, 15, 4132-4144. http://dx.doi.org/10.1016/j.rser.2011.07.007

[16] Alnaser, N.W. (2008) Towards Sustainable Buildings in Bahrain, Kuwait and United Arab Emirates. The Open Construction \& Building Technology Journal, 2, 30-45. http://dx.doi.org/10.2174/1874836800802010030

[17] (2011) Green Economy in the Arab Region: Overall Concept and Available Options. Reference Paper.

[18] World Bank (2013) The Little Data Book 2013. World Bank, Washington DC. http://dx.doi.org/10.1596/978-0-8213-9812-8 
Scientific Research Publishing (SCIRP) is one of the largest Open Access journal publishers. It is currently publishing more than 200 open access, online, peer-reviewed journals covering a wide range of academic disciplines. SCIRP serves the worldwide academic communities and contributes to the progress and application of science with its publication.

Other selected journals from SCIRP are listed as below. Submit your manuscript to us via either submit@scirp.org or Online Submission Portal.
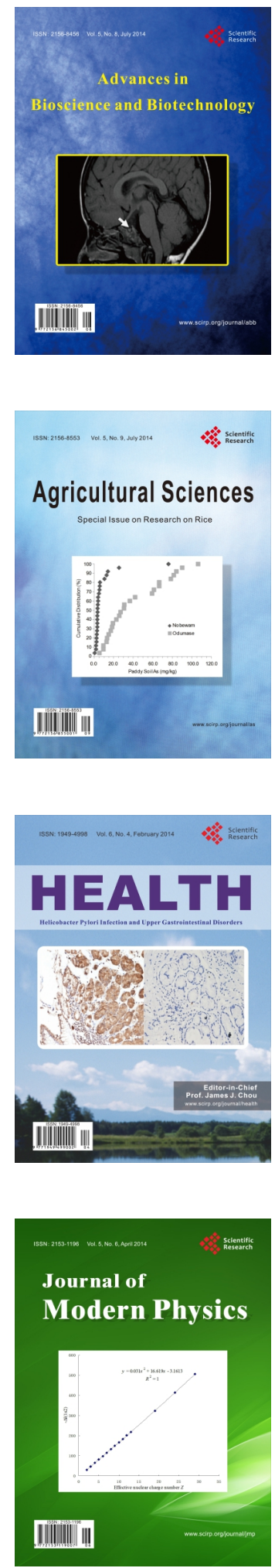
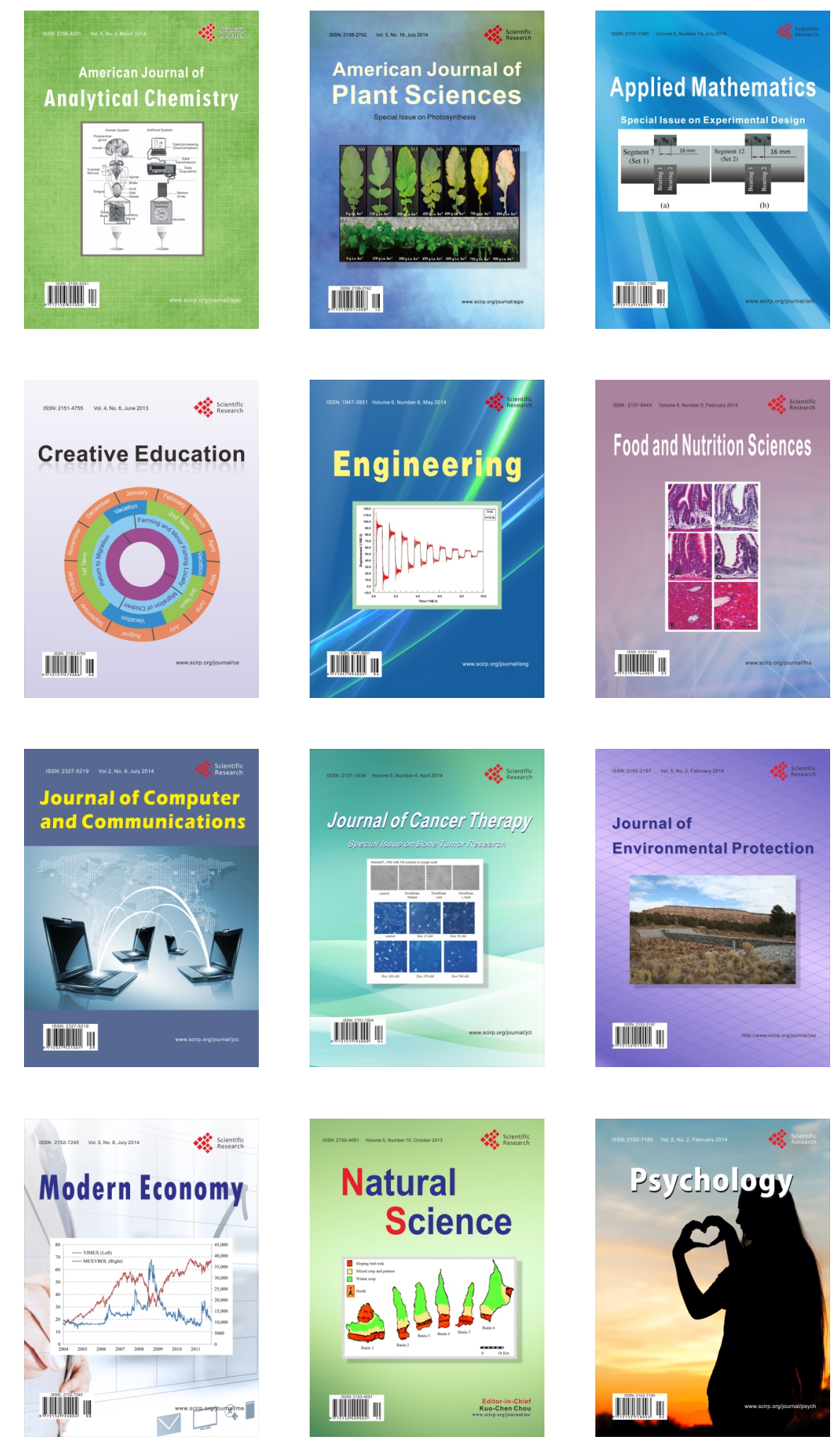